transplantation at four U.S. centers (2). Although well-validated in geriatric patient populations, these instruments had never before been applied to the lung transplant population, and they performed in somewhat disparate fashion. The FFP instrument identified $28 \%$ of wait-list candidates as frail compared with $10 \%$ identified by the SPPB. Thus, only one-third of those identified as frail by the FFP were similarly designated by the SPPB. In contrast, $80 \%$ of those identified by the SBBP were also identified by the FFP. Lacking a gold standard, it is impossible to say whether these performance characteristics reflect poor sensitivity of the SPPB tool or poor specificity of the FFP tool.

After adjustment for multiple potential confounders including LAS, body mass index, and 6-minute-walk test distance, a standard deviation unit increase in frailty assessed by the SPPB tool was associated with a nearly a 2.5 -fold increase in death on the transplant list or delisting. This observation suggests that the presence of frailty is an important prognostic indicator that, if confirmed by future studies, should be incorporated into the calculation of medical urgency for patients awaiting lung transplantation. The same cannot be said about the FFP assessment of frailty, which proved not to be an independent risk factor in the adjusted model.

Although the authors are to be commended for advancing the science of risk assessment for patients with advanced lung disease awaiting transplantation, there are two sides to the lung allocation coin. A system driven exclusively by medical urgency runs the risk of performing transplants on desperately ill candidates with a low likelihood of achieving a successful outcome. To minimize this risk, the LAS allocation system considers not only predicted survival while awaiting transplant (medical urgency) but also survival after transplantation (1). This "net transplant benefit" calculation relies on pretransplant factors that predict 1-year survival posttransplant and seeks to identify candidates for whom transplant is statistically likely to extend short-term survival. A key issue not yet addressed by Singer and colleagues is whether frailty among candidates awaiting transplantation identifies a group at high risk for early posttransplant mortality (2). Intuitively, one would assume this, as frail patients would have marginal physiologic reserves to handle the stress of major thoracic surgery, as well as the additional insults of infection, rejection, and drug toxicities in the posttransplant period. The question is crucial to decisions about candidate selection and organ allocation. If frailty is not demonstrated to be associated with poor posttransplant survival, this would warrant prioritization of candidates with this feature. In contrast, an association with poor posttransplant survival would negate any anticipated net transplant benefit and warrant excluding such patients.

Given current organ shortages, we must remain wise gatekeepers of a scarce resource. Identifying the sickest patients is one part of this obligation; allocating organs to the subset most likely to benefit is the flip side of this very precious coin.

Author disclosures are available with the text of this article at www.atsjournals.org.

Robert M. Kotloff, M.D.

Department of Pulmonary Medicine

Cleveland Clinic

Cleveland, Ohio

\section{References}

1. Egan TM, Kotloff RM. Pro/Con debate: lung allocation should be based on medical urgency and transplant survival and not on waiting time. Chest 2005;128:407-415.

2. Singer JP, Diamond JM, Gries CJ, McDonnough J, Blanc PD, Shah R, Dean MY, Hersh B, Wolters PJ, Tokman S, et al. Frailty phenotypes, disability, and outcomes in adult candidates for lung transplantation. Am J Respir Crit Care Med 2015;192:1325-1334.

3. Fried LP, Tangen CM, Walston J, Newman AB, Hirsch C, Gottdiener J, Seeman T, Tracy R, Kop WJ, Burke G, et al.; Cardiovascular Health Study Collaborative Research Group. Frailty in older adults: evidence for a phenotype. J Gerontol A Biol Sci Med Sci 2001;56: M146-M156.

Copyright @ 2015 by the American Thoracic Society

\title{
Toward Precision Medicine in Pulmonary Arterial Hypertension
}

Pulmonary arterial hypertension $(\mathrm{PAH})$ remains a progressive and fatal pulmonary vascular disease despite advances in care during the last two decades (1-3). Detrimental pulmonary vascular remodeling, in concert with persistent vasoconstriction and additional perivascular changes, occurs as a result of a variety of identified and unidentified local and systemic factors, including enhanced endothelin-1 expression and levels (4-6). Pharmacologic antagonism of the endothelin receptor (via endothelin receptor antagonists [ERAs]) has been an important cornerstone of the therapeutic options available to combat $\mathrm{PAH}$, with improvements in survival, time to clinical worsening, hemodynamics, and

Supported by National Institutes of Health P01 HL grant 108800 (J.E.L. and E.D.A.) and National Institutes of Health K23 HL grant 098743 (E.D.A.). functional performance (7). However, unexplained variability remains with regard to individual clinical response to ERAs and other PAH-specific therapies $(8,9)$. In this issue of the Journal, Benza and colleagues (pp. 1345-1354) advance our understanding of ERA response via the discovery that certain common genetic variations in the endothelin pathway may identify subgroups of patients more or less likely to favorably respond to ERAs (10). This approach may ultimately provide a step toward the application of pharmacogenetics to individualize each patient's PAH treatment.

A modest proportion of PAH cases are strongly associated with rare genetic variations (mutations) in a single gene, although phenotypic expression of disease remains heterogeneous, even in this more focused genetic circumstance (11). For example, bone morphogenetic protein receptor type 2 gene (BMPR2) gene 
mutations are present in more than $75 \%$ of families with heritable $\mathrm{PAH}$, as well as approximately $20 \%$ of idiopathic PAH cases; however, among subjects with the same (or different) BMPR2 gene mutation, there is reduced penetrance as well as clinical PAH variability, including age of onset (12). This highlights the concept that even heritable PAH is not a "single gene disease," as well as the need to identify additional genetic and nongenetic factors responsible for phenotypic heterogeneity. In the heritable $\mathrm{PAH}$ setting, it is likely that a confluence of genetic variations, many common and some rare, interact within the milieu of BMPR2 deficiency to promote $\mathrm{PAH}$ pathogenesis.

Multiple common genetic variants may contribute to phenotypic heterogeneity in the setting of a BMPR2 mutation, although prospective validation studies are needed. Some variants shown to contribute to phenotypic variation include expression of the wild-type BMPR2 allele, TGF $\beta 1$ gene polymorphisms, and polymorphisms related to sex hormone levels (13-15). In addition, genetic polymorphisms associated with the development of nonfamilial forms of PAH have been identified, using both discovery and targeted approaches. These include the recent discovery of a common polymorphism at the CBLN2 locus and gene polymorphisms related to sex hormone levels, as well as in the endostatin and serotonin transporter genes (16-20). However, these, and indeed most genetic variants explored to date, still await independent or prospective validation, or both.

The identification of common genetic polymorphisms in the endothelin pathway that correlate with response to therapy by Benza and colleagues represents a step forward as the field moves to incorporate metrics relevant to individual variability into clinical decision making. More such studies are needed in the pulmonary vascular disease field as we move toward achieving the vision of precision medicine $(21,22)$. Clinical trial publications to date have not closely examined this issue, although supportive data for precision medicine initiatives may exist within some large databases and would be excellent to access for post hoc analyses. In one of the few examples, Gabler and colleagues analyzed pooled data from six randomized placebo-controlled trials of ERAs to evaluate the effect of race and sex on drug response. They found improved clinical response to ERAs with regard to change in 6-minute-walk distance among those identified as white compared with black race, as well as among females compared with males (9). Genetic variation could certainly contribute to these differences. The restriction of the current study to subjects of European descent removes much of the likelihood that ancestry influenced the results of this study, but conversely, it is possible that the findings in the Gabler study of differences in ERA response according to race are a result of variations in common endothelin polymorphisms according to race.

Before endothelin-related gene polymorphisms are incorporated into clinical care, replication is necessary, and ideally, multiple studies will support their findings. Such studies could occur using a variety of approaches, including both traditional research registries of $\mathrm{PAH}$ and well-curated electronic medical record resources with available genome-wide or targeted-genome genotyping. Regardless, the study by Benza and colleagues is hopefully just the tip of the iceberg. To achieve the goals of precision medicine, gene-medicine interaction studies must be performed using all PAH medicines alone and in combination, and applied to subjects of all backgrounds. In addition, the incorporation of additional genomic variations, as well as other factors such as epigenetic variations and environmental exposures, will ultimately be necessary.

The last 2 decades have seen a revolution in PAH therapy, but it is time to migrate beyond a "one-size-fits-all approach" to $\mathrm{PAH}$ care. Just as we now know that heritable PAH is not a simple "single-gene disease," we must recognize that clinical outcomes and responses to therapy in $\mathrm{PAH}$ are modified by multiple factors, including genetic variations, which will be different for each individual. The lofty goals of precision medicine will take time to achieve, and will likely require collaborative approaches across academic and industry-sponsored research programs. Ironically, it is through large patient-based studies that we will ultimately achieve the goal of individualized therapy.

Author disclosures are available with the text of this article at www.atsjournals.org.

Eric D. Austin, M.D., M.S.C.I.*

Department of Pediatrics

Vanderbilt University Medical Center

Nashville, Tennessee

James E. Loyd, M.D.*

Department of Medicine

Vanderbilt University Medical Center

Nashville, Tennessee

ORCID IDs: 0000-0002-1709-9022 (E.D.A.); 0000-0002-5042-7390 (J.E.L.)

*These authors have contributed equally.

\section{References}

1. D'Alonzo GE, Barst RJ, Ayres SM, Bergofsky EH, Brundage BH, Detre KM, Fishman AP, Goldring RM, Groves BM, Kernis JT, et al. Survival in patients with primary pulmonary hypertension: results from a national prospective registry. Ann Intern Med 1991;115:343-349.

2. Humbert M, Sitbon O, Chaouat A, Bertocchi M, Habib G, Gressin V, Yaïci A, Weitzenblum E, Cordier JF, Chabot F, et al. Survival in patients with idiopathic, familial, and anorexigen-associated pulmonary arterial hypertension in the modern management era. Circulation 2010; 122:156-163.

3. Badesch DB, Raskob GE, Elliott CG, Krichman AM, Farber HW, Frost $A E$, Barst RJ, Benza RL, Liou TG, Turner M, et al. Pulmonary arterial hypertension: baseline characteristics from the REVEAL Registry. Chest 2010;137:376-387.

4. Tuder RM, Archer SL, Dorfmüller P, Erzurum SC, Guignabert C, Michelakis E, Rabinovitch M, Schermuly R, Stenmark KR, Morrell NW. Relevant issues in the pathology and pathobiology of pulmonary hypertension. J Am Coll Cardiol 2013; 62:D4-D12.

5. Stewart DJ, Levy RD, Cernacek P, Langleben D. Increased plasma endothelin-1 in pulmonary hypertension: marker or mediator of disease? Ann Intern Med 1991;114:464-469.

6. Giaid A, Yanagisawa M, Langleben D, Michel RP, Levy R, Shennib H, Kimura S, Masaki T, Duguid WP, Stewart DJ. Expression of endothelin-1 in the lungs of patients with pulmonary hypertension. N Engl J Med 1993;328:1732-1739.

7. McLaughlin VV, Shah SJ, Souza R, Humbert M. Management of pulmonary arterial hypertension. J Am Coll Cardiol 2015;65: 1976-1997.

8. McLaughlin VV, Archer SL, Badesch DB, Barst RJ, Farber HW, Lindner JR, Mathier MA, McGoon MD, Park MH, Rosenson RS, et al American College of Cardiology Foundation Task Force on Expert Consensus Documents; American Heart Association; American College of Chest Physicians; American Thoracic Society, Inc; 
Pulmonary Hypertension Association. ACCF/AHA 2009 expert consensus document on pulmonary hypertension a report of the American College of Cardiology Foundation Task Force on Expert Consensus Documents and the American Heart Association developed in collaboration with the American College of Chest Physicians; American Thoracic Society, Inc.; and the Pulmonary Hypertension Association. J Am Coll Cardiol 2009;53:1573-1619.

9. Gabler NB, French B, Strom BL, Liu Z, Palevsky HI, Taichman DB, Kawut SM, Halpern SD. Race and sex differences in response to endothelin receptor antagonists for pulmonary arterial hypertension. Chest 2012;141:20-26.

10. Benza RL, Gomberg-Maitland M, Demarco T, Frost AE, Torbicki A, Langleben D, Pulido T, Correa-Jaque P, Passineau MJ, Wiener HW, et al. Endothelin-1 pathway polymorphisms and outcomes in pulmonary arterial hypertension. Am J Respir Crit Care Med 2015; 192:1345-1354.

11. Austin ED, Loyd JE. The genetics of pulmonary arterial hypertension. Circ Res 2014;115:189-202.

12. Soubrier F, Chung WK, Machado R, Grünig E, Aldred M, Geraci M, Loyd JE, Elliott CG, Trembath RC, Newman JH, et al. Genetics and genomics of pulmonary arterial hypertension. J Am Coll Cardiol 2013;62:D13-D21.

13. Hamid R, Cogan JD, Hedges LK, Austin E, Phillips JA III, Newman JH, Loyd JE. Penetrance of pulmonary arterial hypertension is modulated by the expression of normal BMPR2 allele. Hum Mutat 2009;30: 649-654.

14. Phillips JA III, Poling JS, Phillips CA, Stanton KC, Austin ED, Cogan JD, Wheeler L, Yu C, Newman JH, Dietz HC, et al. Synergistic heterozygosity for TGFbeta1 SNPs and BMPR2 mutations modulates the age at diagnosis and penetrance of familial pulmonary arterial hypertension. Genet Med 2008;10:359-365.

15. Austin ED, Cogan JD, West JD, Hedges LK, Hamid R, Dawson EP, Wheeler LA, Parl FF, Loyd JE, Phillips JA III. Alterations in oestrogen metabolism: implications for higher penetrance of familial pulmonary arterial hypertension in females. Eur Respir $J$ 2009;34:1093-1099.

16. Roberts KE, Fallon MB, Krowka MJ, Benza RL, Knowles JA, Badesch DB, Brown RS Jr, Taichman DB, Trotter J, Zacks S, et al.; Pulmonary Vascular Complications of Liver Disease Study Group. Serotonin transporter polymorphisms in patients with portopulmonary hypertension. Chest 2009;135:1470-1475.

17. Roberts KE, Fallon MB, Krowka MJ, Brown RS, Trotter JF, Peter I, Tighiouart H, Knowles JA, Rabinowitz D, Benza RL, et al.; Pulmonary Vascular Complications of Liver Disease Study Group. Genetic risk factors for portopulmonary hypertension in patients with advanced liver disease. Am J Respir Crit Care Med 2009;179: 835-842.

18. Germain M, Eyries M, Montani D, Poirier O, Girerd B, Dorfmüller P, Coulet F, Nadaud S, Maugenre S, Guignabert C, et al. Genome-wide association analysis identifies a susceptibility locus for pulmonary arterial hypertension. Nat Genet 2013;45:518-521.

19. Willers ED, Newman JH, Loyd JE, Robbins IM, Wheeler LA, Prince MA, Stanton KC, Cogan JA, Runo JR, Byrne D, et al. Serotonin transporter polymorphisms in familial and idiopathic pulmonary arterial hypertension. Am J Respir Crit Care Med 2006;173:798-802.

20. Damico R, Kolb TM, Valera L, Wang L, Housten T, Tedford RJ, Kass DA, Rafaels N, Gao L, Barnes KC, et al. Serum endostatin is a genetically determined predictor of survival in pulmonary arterial hypertension. Am J Respir Crit Care Med 2015;191:208-218.

21. Collins FS, Varmus $\mathrm{H}$. A new initiative on precision medicine. $N$ Engl J Med 2015;372:793-795.

22. Said SI, Hamidi SA. Pharmacogenomics in pulmonary arterial hypertension: toward a mechanistic, target-based approach to therapy. Pulm Circ 2011;1:383-388.

Copyright () 2015 by the American Thoracic Society 